Гринькова Надія

кандидат педагогічних наук, доцент, доцент кафедри теорії і методики виховання Рівненського державного гуманітарного університету, м. Рівне, Україна

ORCID: 0000-0002-5774-8699

e-mail: nadiia.hrynkova@rshu.edu.ua

Стельмашук Жанна

кандидат педагогічних наук, доцент, доцент кафедри теорії і методики виховання Рівненського державного гуманітарного університету,

м. Рівне, Україна

ORCID: 0000-0003-2368-4209

e-mail: zhanna.stelmashuk@rshu.edu.ua

\title{
ФОРМУВАННЯ ЕТИЧНОЇ КОМПЕТЕНТНОСТІ У МАЙБУТНІХ ПЕДАГОГІВ: ЗАСАДНИЧІ ПОЛОЖЕННЯ
}

Анотація. У статті представлено теоретичні та практичні аспекти формування етичної компетентності у майбутніх учителів початкової школи. Узагальнено, що етична компетентність педагога презентує важливі регулятори, цінності і рушійні сили його педагогічної діяльності, що відображаються у принципах, звичках, традиціях як професійної діяльності, так і стають світоглядною основою життя, закріплюючись у свідомій морально-етичній поведінці. Виокремлено такі структурні компоненти етичної компетентності майбутнього педагога: когнітивний, емоційний, мотиваційний та поведінковий. Схарактеризовано показники сформованості етичної компетентності у майбутнього учителя.

Підкреслено важливі напрями роботи щодо становлення етичної компетентності у майбутніх учителів початкової школи - це удосконалення змісту навчальних дисциплін; систематична та цілеспрямована робота кураторів академічних груп 3 виховання студентської молоді, прищеплення їм звичок моральних вчинків та поведінки; залучення студентів до діяльності у проблемних групах та наукових гуртках.

Констатовано, що важливими умовами становлення етичної компетентності майбутнього педагога $є$ побудова суб'єкт-суб'єктної взаємодії між викладачем і студентом на основі діалогічного підходу, принципів гуманізму, демократизму, співробітництва, співтворчості, співдіяльності; ставлення до студента як до особистості, партнера, врахування його інтересів, можливостей, потреб; пошук нових шляхів

(C) Гринькова Н.,

Стельмашук Ж., 2021 


\section{Інноватика у вихованні. Випуск 14. 2021.}

інтенсифікації та оптимізації педагогічного процесу у закладах вищої освіти.

Ключові слова: компетентність, етична компетентність, майбутні учителі початкової школи, формування етичної компетентності, моральноетичні якості, моральна поведінка.

Постановка проблеми. У сучасному суспільстві учитель як суб'єкт і організатор виховного процесу має дотримуватись норм моралі й професійної етики, бути насамперед носієм моральних цінностей, «оскільки освіта стосується життя та успіху людини у суспільстві, іiі фізичного, психічного і духовного здоров'я» (Інститут проблем виховання, 2018).

У Стандарті вищої освіти спеціальність 013 Початкова освіта першого (бакалаврського рівня) однією із загальних компетентностей учителя початкової школи названо «здатність діяти на основі етичних міркувань (мотивів)» (2021). Тому з-поміж ключових компетентностей, які потрібно сформувати у майбутніх педагогів, пріоритетне значення має етична компетентність, оскільки вона $\epsilon$ важливим критерієм особистої та професійної готовності учителя до роботи в школі.

Аналіз останніх досліджень 3 проблеми. Означеній проблемі присвячено чимало досліджень. Питання професійної етики учителя були висвітлені ще у працях радянських психологів та педагогів І. Синиці, I. Чернокозової, Н. Чернокозова, В. Сухомлинського та ін.

Етична компетентність учителя $є$ предметом наукових розвідок Г. Васяновича, К. Гулей, К. Журби, Л. Кравчук, О. Петрук, Л. Хоружої та ін.

Незважаючи на наявні наукові доробки з цієї проблеми, вважаємо необхідним обгрунтування змісту та особливостей формування етичної компетентності майбутніх педагогів у контексті вимог Нової української школи, що і є метою представленої наукової статті.

Виклад основного матеріалу дослідження. «Головне, - це віра в людину, чутливість до всього хорошого в ній. Висока моральність учителя стає нині найважливішою умовою його педагогічної майстерності...», стверджував В. О. Сухомлинський (1977, с.15).

Сучасні підходи, концепції та нормативно-правові акти про освіту ключовим для майбутнього вчителя визначають особистісні моральноетичні якості, які представлені низкою вимог та інтегровані у так звану категорію «етична компетентність».

Аналіз наукових джерел засвідчив, що поняття «компетентність» (від лат. «competentes», «competentis» - відповідний, здібний) трактується як сукупність відповідних знань, які необхідні для ефективної професійної діяльності, а також передбачає оволодіння уміннями, досвідом у певній галузі.

У Законі України «Про освіту» (2017) уточнено сутність поняття: «Компетентність - динамічна комбінація знань, умінь, навичок, способів 


\section{Інноватика у вихованні. Випуск 14. 2021.}

мислення, поглядів, цінностей, інших особистих якостей, що визначає здатність особи успішно соціалізуватися, провадити професійну та/або подальшу навчальну діяльність».

У Професійному стандарті вчителя одним із видів професійної компетентності виокремлена емоційно-етична компетентність, під якою розуміють «здатність усвідомлювати особисті відчуття й почуття, управляти власними емоційними станами; здатність до усвідомленої, конструктивної та екологічної взаємодії з учасниками освітнього процесу в локальних спільнотах; здатність усвідомлювати та поціновувати взаємозалежність людей і систем у глобальному світі» (2020, с.7-8).

Таким чином, саме етична компетентність педагога презентує важливі регулятори, цінності і рушійні сили його педагогічної діяльності, що відображаються у принципах, звичках, традиціях як професійної діяльності, так і стають світоглядною основою життя, закріплюючись у свідомій морально-етичній поведінці, що є однією із вимог концепції Нова українська школа (2016).

Як зазначила Л. Хоружа, особливість етичної компетентності учителя полягає у тому, що вона належить до надпредметних, інтегрованих компетентностей і представляє собою систему знань, умінь, навичок і ставлень, які визначають ефективність його педагогічної діяльності i акумулюють так зване особистісно-моральне ядро (2020, с.31). Отже, вона має інтегрований характер і набувається майбутніми учителями протягом засвоєння всього змісту педагогічної освіти.

Н. Султанова етичну компетентність майбутніх педагогів визначила як «комплексне інтегративне утворення в цілісній структурі особистості фахівця, що характеризує ступінь відображення теоретичних етикопедагогічних знань у практичній площині професійної діяльності, $\epsilon$ показником сформованості особистісних морально-етичних якостей i професійних цінностей, які в комплексі зумовлюють готовність майбутнього фахівця до етично-адекватного виконання професійної діяльності згідно з нормами педагогічної етики (2010). Авторка також наголосила на двозначності змісту етичної компетентності майбутнього педагога, що передбачає, з одного боку, моральність змісту діяльності, а 3 іншого боку, є необхідним психолого-педагогічним інструментом його впливу на учасників освітнього процесу.

Зважаючи на положення освітнього менеджменту, діяльність сучасного педагога Нової української школи необхідно розглядати як невід'ємний компонент i важливий показник управління освітнім процесом у закладах освіти. Ураховуючи дослідження в теорії управління В. Григораша, О. Касьянової, О. Мармази (2016), однією із умов формування етичної компетентності майбутнього педагога $є$ формування у нього системи соціальних якостей: громадянської активності і стійкості переконань, патріотизму, толерантності, соціальної активності, зацікавленості в успіхах учнів, антракції (соціальної установки, яка передбачає повагу кожної особистості), альтруїзму, емпатії, рефлексії 


\section{Інноватика у вихованні. Випуск 14. 2021.}

(здатності до самооцінки), екстравертності, емоційної врівноваженості, вміння здійснювати комунікативну взаємодію в різних сферах, інформаційної та педагогічної культури; а також моральних якостей: чесності, відповідальності, принциповості, наукового світогляду, високої загальної культури та ерудиції, сили волі, валеологічної культури, почуття гумору, порядності, охайності, дисциплінованості, вимогливості, креативності.

Аналіз наукового доробку О. Козиревої, І. Леонтьєвої, І. Кислої, С. Ткаченко, Л. Хоружої уможливив виокремлення таких структурних компонентів етичної компетентності майбутнього педагога: когнітивний (передбачає сформованість системи знань про морально-етичні норми, особливості взаємодії, стилі комунікації; загальнокультурну компетентність, позитивну поведінку); емоційний (передбачає розвинену емпатію та рефлексію, гуманізм та толерантність у взаємодії з людьми); мотиваційний (зумовлений розширенням соціального середовища, відтак, інтересів і мотивацій); потреба у конструктивному спілкуванні; готовність до виявлення етичної компетентності; поведінковий (свідчить про наявність перцептивно-рефлексивних та експресивних умінь; уміння керувати ситуаціями взаємодії, вирішувати конфліктні ситуації тощо).

Проведена наукова розвідка дає підстави для узагальнення показників сформованості етичної компетентності у майбутнього учителя: усвідомлення на рівні переконань змісту національних цінностей, гуманізму, толерантності, морально-етичних норм; пріоритетність морально-етичних норм у педагогічній діяльності; потреба у моральному самовдосконаленні, саморозвитку; систематична етична рефлексія власної поведінки та вчинків; діагностування змісту морально-етичних колізій у відносинах з колегами, учнями та їхніми батьками; побудова комунікації 3 усіма учасниками освітнього процесу на основі загальнолюдських морально-етичних цінностей; уміння розв'язувати міжособистісні конфлікти та навчання цьому своїх учнів.

Формування етичної компетентності у майбутнього педагога $\epsilon$ складним i, водночас, дуже важливим, оскільки $\epsilon$ необхідною передумовою успішної професійної діяльності і вимагає від студента подолання власних стереотипів і звичок, готовності працювати задля майбутнього нашої держави.

Здійснений аналіз науково-методичних досліджень та власний досвід професійної підготовки вчителів початкової освіти на педагогічному факультеті уможливив виокремлення основних шляхів формування етичної компетентності у майбутніх педагогів. Так, важливим напрямами роботи щодо становлення етичної компетентності майбутніх учителів початкової школи на нашу думку, є:

1. Удосконалення змісту навчальних дисциплін циклів загальної, професійної підготовки і вибіркового компоненту, а також введення спеціальних навчальних курсів із педагогічної етики. Зокрема, важливим, на наш погляд, $є$ домінування у змісті дисциплін педагогічного циклу 


\section{Інноватика у вихованні. Випуск 14. 2021.}

(«Основи педагогіки зі вступом до спеціальності», «Теорія і методика виховання», «Дидактика», «Історія педагогіки», «Педагогічна майстерність», а також відповідних методик викладання дисциплін в початковій школі) етико-педагогічний ідей, концепцій, які мають інваріантний характер та спрямовані на збагачення світогляду майбутніх учителів, формування у них ціннісного ставлення до світу та педагогічної професії. Релевантним є також проведення практичних занять у формі семінарів-обговорень, тренінгів, зміст яких визначає формування стійкого мотиваційного підгрунтя, переконань та бажання керуватися у педагогічній діяльності та особистому житті системою морально-етичних цінностей, постулатів.

2. Систематична та цілеспрямована робота кураторів академічних груп з виховання студентської молоді, прищеплення їм звичок моральних вчинків, навчання майбутніх учителів ефективно вирішувати конфліктні ситуації, апелюючи до етичності їх змісту та неписаних правил моралі. Важливою складовою є також дотримання етичних норм поведінки у різних сферах життєдіяльності та професійного дрес-коду. Основними формами роботи при цьому виступають години куратора у формі лекцій, семінарів-обговорень, тренінгів, годин відвертої розмови, думок уголос, самопрезентацій, мотиваційних ігор, а також екскурсій, походів, подорожей тощо.

3. Залучення студентів до роботи й навчання у проблемних групах, наукових гуртках (наприклад, «Барви української народної педагогіки», «Берегиня»), у Школі педагогічної майстерності, сертифікаційних курсах («Аніматорська діяльність»), студентських благодійних організаціях та об’єднаннях (Гринькова, Стельмашук, Ваколюк, 2020) тощо.

Таким чином, робота з формування етичної компетентності майбутніх учителів має системний та багатоаспектний характер, передбачає удосконалення освітнього процесу у змістовому, дидактичному та функціонально-діяльнісному аспектах. Необхідна умова ефективності становлення моральності майбутнього педагога - ціннісне ставлення до студента з боку викладача, повага до його особистості, побудова педагогічної взаємодії на засадах партнерства і співробітництва. Сьогодні, як ніколи, актуальні слова В. О. Сухомлинського: педагога, який не має любові до дитини, можна порівняти із художником без відчуття простору і кольору, співаком без голосу, музикантом без слуху. Щоб достукатися до сердець учнів учитель повинен сприяти налагодженню позитивної атмосфери взаємодовіри, «що можна порівняти з тонким, ледве чутним звучанням струни, коли рука музиканта торкнеться інструмента. Як це нелегко і важливо - досягти гармонійного звучання найчутливішого, трепетного, живого інструмента - дитячої душі!..» (Сухомлинський, 1977).

Висновки i перспективи подальших розвідок. Отже, етична компетентність майбутнього педагога - це одна із важливих умов успішної професійної діяльності вчителя. Вона визначає його особисті якості. На прикладі підготовки студентів педагогічного факультету РДГУ ми 


\section{Інноватика у вихованні. Випуск 14. 2021.}

визначили основні напрями і умови ефективної роботи 3 формування етичної компетентності: побудова суб'єкт-суб'єктної взаємодії між викладачем i студентом на основі діалогічного підходу, принципів гуманізму, демократизму, співробітництва, співтворчості; ставлення до студента як до особистості, партнера, врахування його інтересів, можливостей, потреб; пошук нових шляхів інтенсифікації та оптимізації освітнього процесу у закладах вищої освіти.

Проведене дослідження не претендує на вичерпний аналіз усіх аспектів означеної проблеми. Перспективними вважаємо наукові розвідки в контексті формування професійної компетентності майбутнього педагога.

\section{СПИСОК ВИКОРИСТАНИХ ДЖЕРЕЛ}

Інститут проблем виховання, Інститут модернізації змісту освіти (2018). Програма «Нова українська школа» у поступі до ичнностей. Київ. 40 с.

Міністерство освіти і науки України (2021). Про затвердження стандарту вищої освіти за спеціальністю 013 Початкова освіта першого (бакалаврського) рівня вищої освіти: Наказ № 357 від 23.03.2021. URL: https://mon.gov.ua/ua/osvita/visha-osvita/naukovo-metodichna-rada-ministerstva-osvitii-nauki-ukrayini/zatverdzheni-standarti-vishoyi-osviti]. [Дата звернення 10.10.2021].

Сухомлинський, В. (1977). Вибрані твори : В 5 т. Т. 3: Сериче віддаю дітям. Народження громадянина. Листи до сина. Київ: Радянська школа. 670 с.

Міністерство освіти і науки України (2017). Закон України «Про освіту». URL: https://osvita.ua/legislation/law/2231/ [Дата звернення 10.10.2021].

Міністерство розвитку економіки, торгівлі та сільського господарства України, (2020). Професійний стандарт за професіями «Вчитель початкових класів закладу загальної середньої освіти». https://www.me.gov.ua/Documents/Detail?lang=uk-UA\&id=22469103-4e36-4d41b1bf-288338b3c7fa\&title=RestrProfesiinikhStandartiv [Дата звернення 10.10. 2021].

Кабінет Міністрів України, (2016). Концепція «Нова украӥнська школа». [online]. Режим доступу на: https://mon.gov.ua/ua/tag/nova-ukrainska-shkola [Дата звернення 10.10.2021].

Хоружа, Л. та Леонтьєва I. (2020) Педагогічна етика. Київ: Київський університет ім. Бориса Гринченка, 214 с.

Султанова, Н. (2010) Педагогічні аспекти формування етичної компетентності майбутнього педагога. Педагогічний Альманах, Випуск. 6. С. 155-159.

Григораш, В., Касьянова, О. та Мармаза, О. (2016) Управління навчальним закладом. Харків: Ранок Веста, 2016. 187 с.

Гринькова, Н., Стельмашук, Ж., Ваколюк, А. (2020). Роль волонтерської діяльності у формуванні особистості майбутнього вчителя початкової школи. Інноватика у вихованні. 11(2), сс. 93-102.

\section{REFERENCES}

Institute of problems of education, Institute of modernisation of maintenance of ed ucation (2018). Prohrama Nova ukrainska shkola u postupi do tsinnostei [Program New Ukrainian school in moving toward values] Kyiv. [in Ukrainian].

Ministry of Education and Science of Ukraine. (2021). Pro zatverdzhennia standartu vyshchoi osvity za spetsialnistiu 013 Pochatkova osvita pershoho (bakalavrskoho) rivnia vyshchoi osvity [About the statement of the standard of higher 


\section{Інноватика у вихованні. Випуск 14. 2021.}

education on a specialty 013 Primary education of the first (bachelor's) level of higher education] (Order No 357, dated March 23, 2021). Retrieved from https://mon.gov.ua/ua/osvita/visha-osvita/naukovo-metodichna-rada-ministerstva-osvitii-nauki-ukrayini/zatverdzheni-standarti-vishoyi-osviti [Data zvernennia 10.10.2021]. [in Ukrainian].

Sukhomlynskyi, V. (1977). Vybrani tvory: Vol. 4 [Selected Works]. Kyiv: Radianska shkola. [in Ukrainian].

Ministry of Education and Science of Ukraine. (2017). Zakon Ukrayini "Pro osvitu" [A law of Ukraine is "On education"]. URL: https://osvita.ua/legislation/law/2231/ [Data zvernennia 10.10.2021]. [in Ukrainian].

Ministry of Economic Development, Trade and Agriculture of Ukraine (2020). Profesiinyi standart za profesiiamy "Vchytel pochatkovykh klasiv zakladu zahalnoi serednoi osvity" [Professional standard by profession "Primary school teacher of general secondary education"] Retrieved from https://www.me.gov.ua/Documents/Detail?lang=uk-UA\&id=22469103-4e36-4d41b1bf-288338b3c7fa\&title=RestrProfesiinikhStandartiv [Data zvernennia 10.10.2021]. [in Ukrainian].

Cabinet of Ministers of Ukraine. (2016). Kontseptsiia "Nova ukrainska shkola" [Conception is "New Ukrainian school"] (Regulation No. 988-p., December 14). URL: https://mon.gov.ua/ua/tag/nova-ukrainska-shkola [Data zvernennia 9.05.2019]. [in Ukrainian].

Khoruzha, L. \& Leontieva I. (2020). Pedahohichna etyka [Pedagogical ethics]. Kyiv: Kyivskyi universytet im. Borysa Hrinchenka. [in Ukrainian].

Sultanova, N. (2010) Pedahohichni aspekty formuvannia etychnoi kompetentnosti maibutnoho pedahoha [Pedagogical aspects of formation of ethical competence of the future teacher]. Pedahohichnyi Almanakh, No 6, 155-159. [in Ukrainian].

Hryhorash, V. \& Kasianova, O. \& Marmaza, O. (2016) Upravlinnia navchalnym zakladom [Educational institution management]. Kharkiv: Ranok Vesta. [in Ukrainian].

Hrynkova, N., Stelmashuk, Zh. \& Vakoliuk, A. (2020). Rol volonterskoi diialnosti $\mathrm{u}$ formuvanni osobystosti maibutnoho vchytelia pochatkovoi shkoly [The role of volunteering in shaping the personality of the future primary school teacher]. Innovatyka u vykhovanni [Innovation in education], 11, s. 93-102. [in Ukrainian].

\section{FORMATION OF ETHICAL COMPETENCE FOR FUTURE TEACHERS: BASIC PROVISIONS}

\section{Nadiia Hrynkova}

Candidate of Pedagogical Sciences, Associate Professor, Associate Professor at the Department of Theory and Methods of Education, Rivne State University for the Humanities, Rivne, Ukraine ORCID: 0000-0002-5774-8699 e-mail:nadiia.hrynkova@rshu.edu.ua

Zhanna Stelmashuk

Candidate of Pedagogical Sciences, Associate Professor, Associate Professor at the Department of Theory and Methods of Education,

Rivne State University for the Humanities, 


\title{
Rivne, Ukraine \\ ORCID: 0000-0003-2368-4209 \\ e-mail: zhanna.stelmashuk@rshu.edu.ua
}

\begin{abstract}
The article presents theoretical and practical aspects of the formation of ethical competence for future primary school teachers. It is generalized that the ethical competence of a teacher presents important regulators, values and driving forces of his pedagogical activity, which are reflected in the principles, habits, traditions of professional activity and become the worldview of life, enshrined in conscious moral and ethical behavior. The structural components of the ethical competence for the future teacher are singled out: cognitive, which presupposes the formation of a system of knowledge about moral and ethical norms, features of interaction, communication styles; general cultural competence, positive behavior; emotional - involves developed empathy and reflection, humanism and tolerance in interaction with people; motivational - due to the expansion of the social environment, hence, interests and motivations; the need for constructive communication; readiness to identify ethical competence; behavioral - indicates the presence of perceptual-reflexive and expressive skills; ability to manage interaction situations, resolve conflict situations, etc. The structural components of the ethical competence of the future teacher are singled out: cognitive, emotional motivational and behavioral. The indicators of formation of ethical competence in the future teacher are characterized.

It is stated that important areas of work on the formation of ethical competence of future primary school teachers are: improving the content of academic disciplines; systematic and purposeful work of curators of academic groups on education of student youth, instilling in them habits of moral actions and behavior; involvement of students in activities in problem groups and research groups.

Work and study in problem groups, scientific circles. It is concluded that important conditions for the formation of ethical competence of the future teacher are: building a subject-subject interaction between teacher and student based on a dialogical approach, the principles of humanism, democracy, cooperation, co-creation, cooperation; attitude to the student as a person, partner, taking into account his interests, opportunities, needs; search for new ways to intensify and optimize the pedagogical process in higher education institutions.

Keywords: competence, ethical competence, future primary school teachers, formation of ethical competence, moral and ethical qualities, moral behavior.
\end{abstract}

Стаття надійшла до редакиії 06.10.2021 p. 